\title{
Innovation at Scott Farms, Tirau
}

\author{
IAN SCOTT \\ Oraka Deer Farm, 71 Bayly Road, Tirau RD1
}

\section{Introduction}

I run a mixed enterprise, dairy, deer and maize growing farm based on high value Tirau ash soils situated between Tirau and Matamata. Many neighbouring farms are being purchased for vegetable cropping as urban spread in Auckland forces the likes of Balle Bros and Wilcox \& Sons further south. I continue to practice as a large animal veterinarian primarily serving dairy farmers, but also meeting quality assurance and animal welfare needs of the deer industry. After 35 years working with farmers, I am still amazed by the skill, inventiveness and sheer creativity demonstrated by so many of my clients.

\section{Farm Description}

- Home block: 108 ha (58 ha milking platform, 8 ha farm forestry, 42 ha 400 deer)

- Lake Road: 50 ha support (8 ha bulls and calves; 40 ha maize and annual ryegrass, 400 to 480 tonnes maize silage sold annually)

- Oliver Farms: 70 ha (700 deer and calves yr 1)

- Off Farm: replacements and sale heifers

\section{Dairy Production}

It has taken 5 years to move production from 58000 $\mathrm{kg}$ MS on 50 ha to 138000 on 58 ha + support block. The current operation is System 5 in the DairyNZ classification. It is seasonal supply, with split herds to allow targeted feeding. Inputs/cow amount to 3-3.5 tonnes per cow during the lactation.

Lake Road, the support block grows $30 \mathrm{t} / \mathrm{ha:} 25 \mathrm{t}$ maize and $5 t$ annual ryegrass

The cows are grazed at Lake Road on annual ryegrass from late May, returning to the Home block for calving, July-September

All heifers are synchronised, AI, positives kept, and brought home in winter to calve week one.

\section{Inputs}

Input system needs to be simple, no mixer wagon, yeast, bypass fats etc. Needs to be done by staff.

PKE (NB. the quality is declining with less oil and more burnt undigestible charcoal), maize grain, DDG, kiwifruit, Tapioca.

Maize silage 420-450 t/year produced; $150 \mathrm{t}$ for deer Winter grazing whole herd on annual ryegrass.

\section{Pasture management}

Integration of deer and cows. Mature hinds maintain pasture quality in spring while allowing higher residual grazing levels to increase per cow productivity and improve mating performance. The deer are exceptionally good at removing weeds and improving pasture density.

In winter when the whole herd is on annuals, weaner deer are used in the deer-fenced part of the dairy farm to maintain a pasture wedge for returning cows to enhance early lactation production.

Parasite challenge is the biggest problem for young deer growth rates. Using parasite-free dairy pastures enhances deer performance and enhances sustainability by reducing dependence on chemical endectocides.

No supplements are made on the deer or dairy platform. If the deer can't keep up with maximum spring growth, then cow grazing extends into the deer farm and inputs are scaled back. Round bales are way too expensive.

\section{Deer production}

- Velvet: $1.5 \mathrm{t}$

- Venison: 400+ carcasses 65-70 kg av

- Trophies: 8-10 per year, best $\$ 50000$ average $\$ 6000-8000$ (recent world record - bow shot $593 \mathrm{SCI}$ )

Export stud stock: Recently sent first shipment from New Zealand by air back to Europe; I have also sent deer to China. Exports of deer are to improve the trophy potential in European estates.

Terminal sire sales in New Zealand: Oraka Deer Park was the major supplier to Landcorp for terminal sires. This aspect of the business is declining as deer farmers become extinct.

\section{Challenges}

Staff

Running high input high stocking rate operations is not simple, especially for me, as I can't be full time handson: I have 35 other farmers and their 16000 cows all with their own problems and issues that they want me to solve. It is not a question of good cows and a nice farm as outsiders and staff like to think. It is very hard work and you need excellent planning as well as welldeveloped anticipation and intuition. At $5.2 \mathrm{cows} / \mathrm{ha}$ a surplus becomes a deficit in the blink of an eye. 
You need to sense changes almost before they can be measured and mud and pasture damage happens while others relax by the fire oblivious to risk. Progress is made by 100 incremental gains. I, like many others, am finding that people arriving from overseas, particularly Asian countries, have the attitude, the work ethic and sheer mental agility and skills that we need on farm. This difference appears to reflect the fact that at school our children have been told that agriculture has a limited future and careers advisors steer those with the required talent in another direction. After overcoming language and cultural barriers and provided with the appropriate in job training, the overseas people become highly valued team members.

\section{Pastures}

I am over new pastures. I did as science suggested and renewed a lot of the farm. In the first big drought AR1's did not perform well. I was told AR37 would be just the ticket, but with well-fed cows, palatability is poor and my deer don't like these at all. If the bugs don't like it, neither do well fed animals! Don't do trial work with poorly-fed, grass-only cows. They don't know what choice is. (NB. Elk are by far the best animals for trials on endophyte. They have never encountered them during evolution so they react to the slightest challenge, especially ergovalines where cattle don't show signs that are easily measured.) In last year's drought the new grasses didn't persist either. My old untouched pastures recovered in the shortest time and re-tillered to a dense, weed free sward but the others...And don't talk of over grazing. With 5.2 cows/ha and a severe drought, withstanding grazing pressure is a necessary attribute, not a luxury. Now I have to hire a tractor driver in autumn just to renew weak pastures. In any industry where the advertising budget is bigger than the product development expenditure you have to consider that you are dealing with a fashion trend not pure science. My mail box has been strengthened and enlarged to cope with autumn grass seed brochures! I now plant chicory under-sowed with annuals in winter, then sprayed and re-boosted with chicory in year two. I don't believe New Zealand's future productivity gains will be driven by new ryegrass strains.

\section{Sustainability and environmental protection}

This is the new tomorrow and every CEO of a research institution rubs his hands with glee when he sees a research proposal with sustainability as a central theme...instantly fundable. But we have some very hard calls to make as a nation and as individual farmers. OVERSEER as a regulatory tool is not the simple answer everyone would like and top farmers are likely to be penalised by a one size fits all approach. Much work needs to be done. Should I be penalised for leaching a little too much $\mathrm{N} / \mathrm{ha}$ when I produce over twice the national average/ha? And how about greenhouse gases? Does New Zealand want extra exports to sell and drive prosperity or should we be able to drive from Remuera to Ruapehu each fine weekend in winter to go skiing? Driving $10000 \mathrm{~km}$ in a Camry produces the same carbon dioxide equivalents as one cow driving the economy. And the money from exports coming into the country supports the lifestyles of everybody.

\section{High inputs equates to high risk}

The combination of low pay-outs and drought or other adverse climatic changes put severe mental and financial

Table 1. Scott farm production and local and regional data (Fonterra and New Zealand Dairy Statistics 2011-2012 season)

\begin{tabular}{lccc}
\hline & Scott Farms & South Waikato & Waikato \\
\hline Herd size & 300 & 374 & 327 \\
Effective ha & 57 & 128 & 116 \\
Cows/ha & 5.2 & 2.91 & 2.82 \\
Litres/herd & 1595249 & 1674560 & 1288351 \\
Kg milkfat/herd & $78697^{\star}$ & 82333 & 63566 \\
Kg protein/herd & $59126^{\star}$ & 63071 & 48144 \\
Kg milksolids/herd & $137796^{\star}$ & 145404 & 111710 \\
Kg milkfat/ha & 1381 & 641 & 548 \\
Kg protein/ha & 1037 & 491 & 415 \\
Kg milksolids/ha & 2417 & 1132 & 963 \\
Kg milkfat/cow & 262 & 220 & 195 \\
Kg protein/cow & 197 & 169 & 147 \\
Kg milksolids/cow & 459 & 389 & 342 \\
\hline
\end{tabular}

*70 additional replacements reared on whole milk for sale $=3370 \mathrm{~kg}$ MS extra consumed above normal replacement level. These data include the extra milk consumed by the calves. 
challenges ahead of those involved. You must have mental ability and monetary reserves to cope. Not Negotiable.

\section{Things I am doing to improve sustainability:}

- integration across species, use deer to do topping despite "recent discovery" by Lincoln Dairy farm that topping improves production. I don't even burn diesel... just grow venison.

- less dependence on chemical worm control in deer.

- graze my cows on maize ground over the major leaching period of winter, early spring where deeper maize roots can recover lost $\mathrm{N}$ from deep in the soil profile.

- drive productivity gains with maize silage/PKE which reduces $\mathrm{N}$ loss $/ \mathrm{kg}$ MS produced.

- recycle nutrients from feed pad waste back to maize support platform to reduce $\mathrm{N}$ loading on dairy platform and reduce fertiliser needed for maize.

- extend effluent irrigation onto deer farm where losses are low.

- nutrient budget on dairy platform and monitor farm organic matter on continuous cropping unit. Organic matter is increasing under this current approach.

- protect and enhance the physical environment by total stock exclusion and Lake Okoroire restoration project. This is a $\$ 120000$ plus project to restore the only South Waikato peat lake, jointly funded by Waikato Regional council, South Waikato District council, Government Biodiversity fund and Fonterra. The project is managed ably by my daughter, Alana, and draws on a host of community and university support volunteers. Funding shortfalls and behind the scenes inputs are the responsibility the farm owner! These responsibilities shouldn't be underestimated.

\section{The Future}

A new covered herd shelter is being planned for this year. Using wood chip flooring this will enable virtually all herd shelter/feed pad nutrients to be recovered and recycled to the support farm, further reducing $\mathrm{N}$ leaching and improving soil structure. I cannot see that the current explosion of anaerobic ponds is the answer to our effluent problems. All we have done is swap $\mathrm{N}$ leaching (something we think we can measure) for greenhouse gases (something a lot trickier to measure, let alone capture). Farm trees for chipping may be a new valuable resource.

Sadly my farming venture is partly reliant on New Zealand's red meat processing industry, and despite years of pressure to change, it has doggedly resisted farming attempts at reform and continues to underdeliver financially. The latest efforts seem to be heading the same way. Huge financial investments in genetics, smart farming systems, better feeding and a stubborn determination to persist with an animal which has so much the world needs, cannot counter the pressure that so many sheep, beef, and now cropping farmers have faced before me; either I continue to expand my dairy operation or be reduced to a peasant on my own high quality asset. My children will not thank me for the wrong choice but as a nation and the planet the decisions are never quite so simple. 
